\title{
BEE FORAGE MAPPING BASED ON MULTISPECTRAL IMAGES LANDSAT 8
}

\author{
Moskalenko A., Ph.D., \\ National University of Life and Environmental Sciences of Ukraine \\ e-mail:moskalenko_a@nubip.edu.ua
}

\begin{abstract}
Possibilities of bee forage identification and mapping based on multispectral images have been shown in the research. Spectral brightness of bee forage has been determined with the use of satellite images. The effectiveness of some methods of image classification for mapping of bee forage is shown.
\end{abstract}

Keywords: bee forage, mapping, multispectral images, image classification.

\section{Introduction.}

Ukraine is among the countries with developed beekeeping [1]. Beekeeping can develop effectively only provided of fodder stability. It is provided by the presence of nectar and pollen cultures. Recently, as a result of human intervention in nature, the state of bee forage area has changed significantly: the number of wild nectar and pollen plants reduced, swing open natural land [1]. Area of nectar plant and wood crops annually changes and requires accounting in terms of assessing fodder.

However, there is a need to study new approaches to the definition of operational areas bee forage and its mapping over large areas.

Remotely sensed data, satellite imagery and other spatial data is an impotant input to many analyses. The availability of these data provides opportunities for environmrntal studies particularly in the areas of change detection, land use mapping, land evaluation, land survey that would have been unknown of only a few decades ago.
The remote sensing data can be an important source of geospatial information for visibility, speed and obtaining objective data.

In this concern the aim of the research is to design approaches for account area of bee forage while managing beekeeping development in the region based on remote sensing data.

\section{Analysis of recent research and publications.}

The question of improving the efficiency of forage for beekeeping were the subject of study many scientists: G. Grechka, A. Cherkasov and others [1-3].

Research based on the remote sensing data for forest inventory has been shown in papers of O. Girs, P. Lakyda, V. Myronyuk and others [4-6].

The application of remote sensing data for the thematic mapping of agricultural resources were highlighted in the works of S. Kokhan, M. Slobodyanyk, V. Antonenko, V. Zatserkovnyy and others. [7-9]. 
However, the literature doesn't show approach to identification and mapping the territory of bee forage areas based in remote sensing.

Article purpose - the analysis of the possibility of using remote sensing data for identification and mapping the territory of bee forage.

\section{Materials and methods.}

The process of bee forage mapping based on remote sensing data considered of the following steps:

$\checkmark \quad$ determination of the brightness of the reflected electromagnetic radiation of nectar and pollen plants in different spectral bands of Landsat 8;

$\checkmark \quad$ classification of remote sensing data to identify of bee forage crops;

$\checkmark \quad$ estimate the probability of classification;

$\checkmark \quad$ mapping and identification of areas of bee forage.
The area mapped is territory of Borispilskyi district of Kyiv region.

The Idrisi Selva software tools has been used to digital image processing.

\section{The main material research.}

In total over 1000 species, belong to of honey plants, but the production values are only 40-50 species [3].

Characteristics of the brightness of the observed objects. The source of information about plants in our study are reflected electromagnetic radiation that was fixed on remote sensing data. The study was used data from six spectral bands of satellite images Landsat 8: blue (0,433-0,453 micrometers), green $(0,450-0,515$ micrometers), red $(0,525$ 0,600 micrometers) and three near-infrared $(0,630-0,680$ and $0,845-0,885$ 1,560-1,660 micrometers). Date-13/07/2016 sensor OLI.

In this study, as the main bee forage was chosen:

$\checkmark \quad$ nectar plants - white acacia;

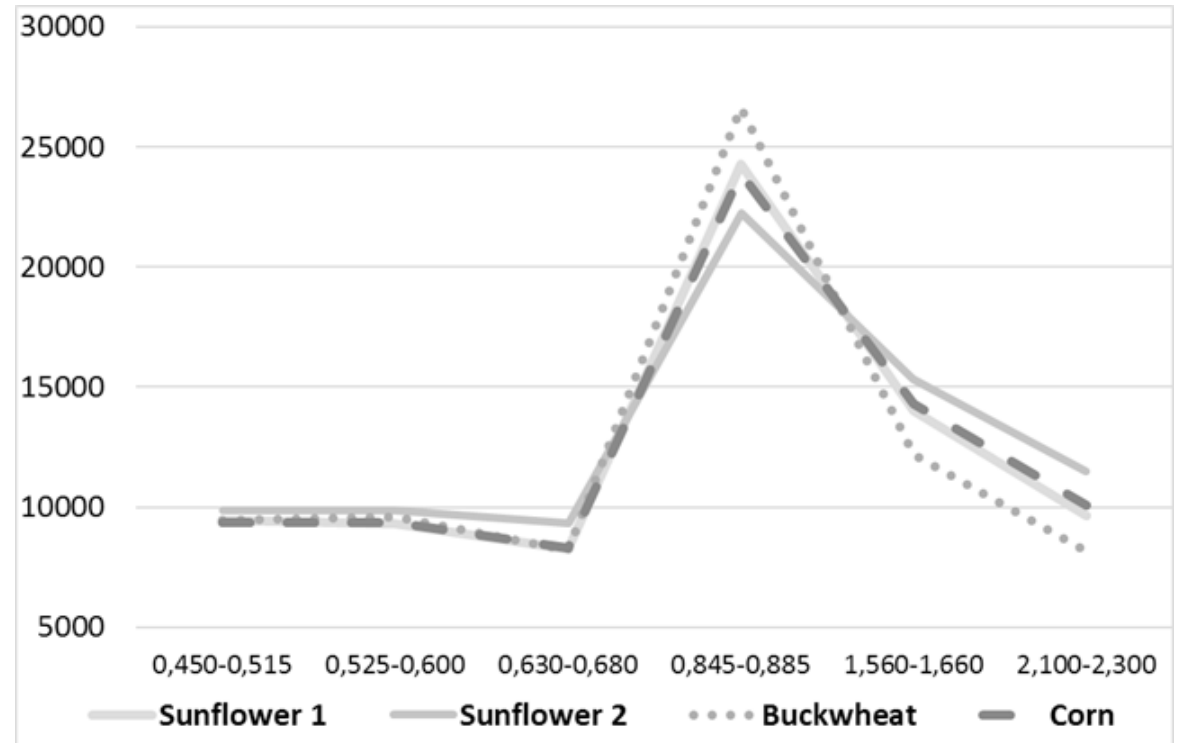

Fig. 1. Curves values of reflected electromagnetic radiation for crops (main crops of bee forage). 
$\checkmark \quad$ plants from which the bees are equally nectar and pollen - buckwheat, sunflower, clover;

$\checkmark$ pollen plants (of which the bees take pollen only) - birch, willow, corn.

For each of the studied plants measurements have been done of electromagnetic reflected radiation and then were build. Fragment chart shown in fig. 1 .

The study investigated plants in the one-time moment, but they had different phase of development. At the time of the study had a different meaning of reflected electromagnetic radiation for sunflower, due to the different phases of the crop.

Classification. Thematic maps has been created by classification remote sensing images. Identifying bee forages was based on methods of the supervised classification.

The starting point of the supervised classification includes the finding typical fields, which contain cultures of honey resources. To investigate the bee forage areas the training sites were. They were selected for nectar and pollen plants, and for other «background» objects: waters, buildings, roads and plants that have no honey values.

The study shows using supervised classification methods for the identification and mapping of bee forage. They are contained a set of «hard classifier» methods: the Minimum Distance to Means, the Maximum Likelihood and the parallelepiped classification of remotely sensed data based on information contained in a set of signature files.

The best result for identification of sunflower was method of the Minimum Distance to Means.

Assessment of the likelihood classification. Assessment of the likelihood classification used Kappa index, which made by comparing a multi-category map of «reality» versus some «alternative» map. The Kappa index given coefficient to assess the probability of classification and consideration of amendments by random. Reality map is a map of cultures on fields that created based on surface data research. This map have high accuracy. Alternative map is a map, which was classification results of remote sensing images.

Accuracy creating thematic maps to identify Sunflower is more than $80 \%$.

Mapping. A set of thematic maps that has the potential of visual impression for assessing of honey resources has been created. Remote sensing data Landsat 8 was used to create thematic maps in the scale 1:100000 and smaller in the region.

\section{Conclusions.}

Possibilities of bee forage identification and mapping based on multispectral images Landsat 8 have been shown in the research. The satellite images can be used to determine areas of cultures that are resource for nectar and pollen such as sunflower.

The methodology and deliverables of the research allow to using the new planning guidelines to account area of bee forage while managing beekeeping development in the region.

The prospect of further research in this direction is to examine and compare the different methods of classification for the use of remote sensing data for identification and mapping of fodder beekeeping. In addition, future research will be cover different periods of growth and selection of the optimal period for assessing of honey resources.

\section{References:}

1. Hrechka, H. M. Suchasnyy medozbir i yoho vykorystannya bdzholynymy simyamy [Modern nectar resourses and use of bees]: https://sites.google.com/site/ukrainskaastepnaa/ucenye-ob-ukrainskoj-stepnoj-porode-pcel/sucasnij-medozbir-i-jogo-viko- 
ristanna-bdzolinimi-sim-ami

2. Matvyets, A.H. (1990). Puty uluchshenyya kormovoy bazы pchelovodstva $v$ ahrotsenozakh lesostepnoy zoni ukraynskoy SSR [Ways to improve forage agrocenoses beekeeping in the forest steppe zone Ukrainian SSR]. Beekeeping, 19, 35-39.

3. Cherkasova, A.I., Blons'ka., V.M., Huba, P.O., Davydenko, I.K., Yatsun, O.M., Voznyy, P.A., Mukvych, N.V. (1989). Beekeeping, K., 304.

4. Giers, O. Myroniuk, V. Kutya, M. (2012). Rozpiznavannya lisoparkovykh landshaftiv zelenoyi zony m.Kyyeva za danymy DZZ [Forest park identification of Kyiv green zone using remote sensing data]. Scientific reports of the National University of Life and Environmental Sciences Ukraine, 7(36) -http://www.nbuv. gov.ua/e-journals/Nd/2012_7/12goa.pdf

5. Hlitukha, D.V., Lakyda, P.I. (2014). Parametrychna struktura derevostaniv za danymy suputnykovykh znimkiv nadvysokoho prostorovoho rozriznennya [Parametric structure stands according to satellite images of high spatial differentiation]. Balanced Nature, 1, 32-36.

6. Myronyuk, V.V. (2015). Perspektyvy vykorystannya k-NN metodu klasyfikatsiyi kosmichnykh znimkiv dlya lisovoyi inventaryzatsiyi Ukrayiny [Prospects of kNN method of classification of satellite images for forest inventory Ukraine]. Balanced Nature, 2, 9-15.

7. Kokhan, S.S. Moskalenko, A.A. (2011). Osoblyvosti klasyfikatoriv zobrazhen' pry vyvchenni stanu silskohospodarskykh kultur [Features classifications images in the study of agricultural crops]. Life and Environmental Sciences, 1-2, 198-204.

8. Kokhan, S.S. (2011). Zastosuvannya vehetatsiynykh indeksiv na osnovi seriyi kosmichnykh znimkiv IRS-1D LISS-III dlya vyznachennya stanu posiviv silskohospodarskykh ku'tur [Application of vegetation indexes derived from satellite images IRS-1D LISS-III for determination of crop status]. Space Science and Technology , 17 (5), 58-63.
9. Slobodyanyk, M.P. (2014). Prohnozuvannya vrozhaynosti sil's'kohospodars'kykh kul'tur za materialamy DZZ ta vehetatsiynymy indeksamy [Forecasting crop yields based on $\mathrm{RS}$ and vegetation index]. Journal of Geodesy and Cartography, 6, 16-20.

10. Kokhan, S.S., Vostokov, A.B. (2009). Dystantsiyne zonduvannya Zemli: teoretychni osnovy [Remote sensing: the theoretical basics]. Kyiv, 511.

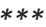

\section{Москаленко А.А.}

КАРТОГРАФУВАННЯ КОРМОВОЇ БАЗИ БДЖІЛЬНИЦТВА ЗА ДАНИМИ LANDSAT 8

Розглянуто можливості ідентифрікації кормової бази бджільництва та їі картографування на основі мультиспектральних зображень. Спектральна яскравість кормової бази бджільничтва була визначена з використанням супутникових знімків. Показано ефективність деяких методів класифрікації зображень для відображення кормової бази бджільництва.

Ключові слова: кормова база бджільничтва, картографування, мультиспектральні зображення, класифрікація зображень.

Москаленко А.А.

КАРТОГРАФИРОВАНИЕ КОРМОВОЙ БАЗЫ ПЧЕЛОВОДСТВА ПО ДАННЫМ LANDSAT 8

Рассмотрены возможности идентификации кормовой базы пчеловодства и ее картографирование на основе мультиспектральных изображений. Спектральная яркость кормовой базы пчеловодства была определена с использованием спутниковых снимков. Показана эффрективность некоторых методов классификации изображений для отображения кормовой базы пчеловодства.

Ключевые слова: кормовая база пчеловодства, картографирование, мультиспектральные изображения, классификация изображений. 